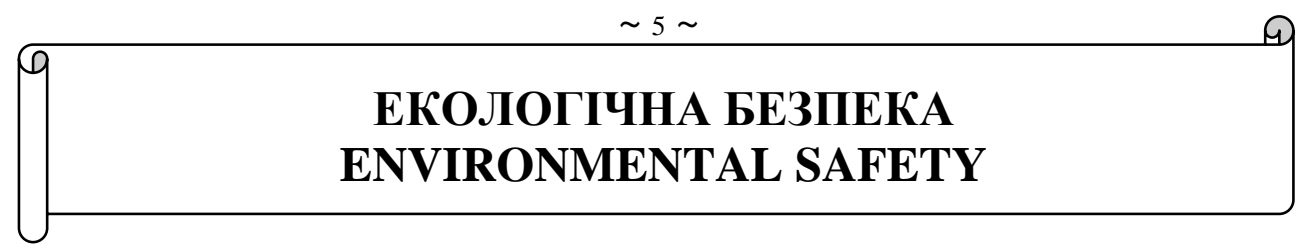

UDK 628.35: 651.6: 556.3

Tamara S. Airapetian ${ }^{1}$, Ph. D., Associate Professor of Department of Water supply, sewerage and purification of waters

Sergii V. Telyma², Ph. D., Senior Research Associate

e-mail: office@hydromech.com.ua

Oleksandr Ya. Oliynyk ${ }^{2}$, Corresponding member of NASU, D. S., Professor, Head of Department

e-mail: OliinikOYa@nas.gov.ua

${ }^{1}$ O.M. Beketov National University of Urban Economy in Kharkiv, Ukraine

${ }^{2}$ Institute of Hydromechanics National Academy of Sciences of Ukraine, Kyiv, Ukraine

\title{
THE METHODIC OF MODELING AND CALCULATIONS OF THE OXYGEN REGIME AT THE PURIFICATION OF THE WASTE WATERS IN AEROTANKS WITH SUSPENDED AND FIXED BIOCENOSIS
}

\begin{abstract}
The methodic of mathematical modeling and calculations of oxygen regime at biological treatment of waste waters from organic contaminants in aerotanks with suspended and fixed biocenosis is given. The peculiarities of the simulation of oxygen supply during purification in aerotanks-mixers and aerotanksdisplacers are considered at this.

Keywords: model; purification; oxygen; organic pollution; aerotank-mixer; aerotank-displacer; biofilm; active sludge.
\end{abstract}

\section{Introduction}

In biological waste waters treatment reactors in particular in aerotanks the removal of organic contaminants (OC) occurs in aerobic conditions that is when oxygen is consumed for biooxidation of OC and self-oxidation of cell material and also used in other processes that may occur at this time. Therefore the modeling and development of the aeration system is to provide such an oxygen regime in the reactor in which the rate of the biological treatment process should not be limited by the amount of oxygen contained in the reactor. In such reactors the processes of dissolution and consumption of oxygen develop simultaneously and are interconnected. In well-known bioreactors - aerotanks the removing of OC occurs under normal conditions only owing to suspended biocenosis (active sludge) and these processes are sufficiently thoroughly considered in the special literature.

(C) T.S. Airapetian, S.V. Telyma, O.Ya. Oliynyk, 2018 
In this paper the peculiarities that occur at the modeling of the oxygen regime in the aerobic biological treatment of waste waters in aerotanks-mixers and aerotanksdisplacers with suspended and fixed biocenosis are considered for conditions when the process of biochemical oxidation is provided with oxygen in sufficient quantities and the oxygen supply will not limit the kinetics of biooxidation (removal) of OC in aerotanks with suspended and fixed biocenosis [1].

\section{The main features of the proposed methodic}

It is known that depending on the hydrodynamic conditions of the flow of the waste waters in bioreactors its are divided on the aerotanks-mixers and aerotanksdisplacers [1-4]. If we take into account that oxygen supply takes place using the most commonly used in practice pneumatic (bubble) oxygen delivery technology in the volume of aerotanks due to the use of air then the indicated features of using oxygen with suspended and fixed biocenosis in particular are as follows. If suspended biocenosis (particles of active sludge) is directly used for oxidation of oxygen dissolved in waste waters from oxygen bubbles then in the case of fixed biocenosis (in the form of a biofilm loaded on the surface of the material) it is necessary to determine the flow of dissolved oxygen that enters to the biofilm surface through the boundary layer of the liquid and carry out a quantitative assessment of the consumption of oxygen by microorganisms in the thickness of the biofilm. The solution of these questions allows us to estimate the amount of oxygen needed for biooxidation by suspended and a fixed biocenosis and moreover allows solving such an important question which of the substrates (oxygen or OC) will limit the oxidation process in the biofilm. It has been established by research that at considerable (saturated) arrangement in the aerotank (reactor) of the elements of loading the oxygen can enter in the biofilm not only from the volume of liquid (dissolved oxygen) but also as a result of so-called inter-surface transfer (IST) directly from the bubbles adhering to the surface of the biofilm. The account of IST allows in some cases to increase the concentration of oxygen entering to the biofilm up to 20\% [2].

In both cases of the removing of organic contaminants by suspended and fixed biocenosis in aerotanks for growth and livelihoods of microorganisms it is necessary to provide the uninterrupted supply of oxygen and to control its consumption in the amount necessary to maintain the kinetics of reactions with a high rate of utilization of $\mathrm{OC}$ in these conditions of the aerobic process. In this work in order to evaluate and analyze the oxygen regime in aerotanks-mixers and aerotanks-displacers under the indicated conditions a general mathematical model was constructed which reduces to the realization of the corresponding equations of the material balance recorded relative to the concentration of oxygen $\mathrm{C}$.

So for aerotank-mixer we have

$$
W_{p} \frac{\partial C_{a}}{\partial t}=Q_{a}\left(C_{0}-C_{a}\right)+W_{p} \alpha K_{C} a\left(\beta C_{p}-C_{a}\right)-F_{\delta_{l}} N_{c}-R_{a_{c}} W_{p}
$$

and for the aerotank-displacer we have

$$
\varepsilon \frac{\partial C_{a}}{\partial t}=D_{c} \frac{\partial^{2} C_{a}}{\partial x^{2}}-v \frac{\partial C_{a}}{\partial x}+\varepsilon \alpha K_{C} a\left(\beta C_{p}-C_{a}\right)-\frac{F_{\delta_{l}}}{W_{p}} N_{c}-R_{a_{c}}
$$




$$
R_{a_{c}}=R_{c_{a}}+R_{c_{c}}
$$

In practical calculations it is enough to consider equations (1)-(2) in stationary conditions and to evaluate their members taking into account the known diffusion criterion of Peckle $P e=\frac{v l}{D_{c}}$ according to [1]. For further implementation let's bring them to the form:

for aerotank-mixer

$$
\begin{gathered}
C_{0}-C_{a}+\alpha K_{C} a\left(\beta C_{p}-C_{a}\right) T_{a}-R_{3}=0, \\
R_{3}=\frac{F_{\delta_{l}}}{Q_{a}} N_{c}+R_{a_{c}} T_{a}, \quad T_{a}=\frac{W_{p}}{Q_{a}},
\end{gathered}
$$

for aerotank-displacer

$$
-v \frac{d C_{a}}{d x}+\varepsilon \alpha K_{C} a\left(\beta C_{p}-C_{a}\right)-\lambda_{e} N_{c}-R_{a_{c}}=0, \quad \lambda_{c}=\frac{F_{\delta}}{F} .
$$

In general case in the above equations the value of the flow of oxygen entering to the biofilm through its surface is determined by the equation:

$$
N_{c}=-D_{c} \frac{d C}{d z}=(1-\eta) K_{C}\left(C_{a}-\left.C\right|_{z=0}\right)+\eta \alpha K_{C n}\left(\beta C_{p}-\left.C\right|_{z=0}\right)
$$

where $\eta$ - the ratio of the surface area of the biofilm in contact with air bubbles to the total surface area of the biofilm.

In other words the equation (5) takes into account the possible additional flow of oxygen into a biofilm both from the volume of liquid in the form of dissolved oxygen and as a result of the so-called inter-surface transfer (IST) directly from the bubbles adhered to the biofilm. The expediency of taking into account IST takes place with sufficiently significant (saturated) of loading of the elements in the aerotank (reactor) which takes place for example in flooded filters with sand-gravel material of loading. In aerotanks with fixed biocenosis (biofilm) it is possible ignoring the IST and some possible positive impact of IST will go into the stock of the calculations. In this case at implementing models it is necessary to take $\eta=0$ and take into account only the flow of dissolved oxygen from the volume of liquid to the biofilm due to diffusion:

$$
N_{C}=-D_{C} \frac{d C}{d z}=K_{C}\left(C_{a}-\left.C\right|_{z=0}\right)
$$

Note that the determination of the flow of oxygen through the surface of the biofilm $N_{c}$ and for the quantitative estimation of the removal of the OC by the biofilm depending on their parameters in particular which of the substrates (pollution or oxygen) limits the purification process in the biofilm is obtained as a result of 
solving the following equations which characterize the consumption of oxygen in the removal of OC by a fixed biocenose (biofilm).

In general this equation for a biofilm has the following form:

$$
\frac{\partial C}{\partial t}=D_{C} \frac{\partial^{2} C}{\partial z^{2}}-R_{C}
$$

In the case of cylindrical loading elements in which the biofilm is formed the equation for the biofilm will be as follows:

$$
\frac{\partial C}{\partial t}=D_{C}\left[\frac{\partial^{2} C}{\partial r^{2}}+\frac{1}{r} \cdot \frac{\partial C}{\partial r}\right]-R_{C}
$$

According to the analysis the solution of equations (7)-(8) for practical calculations is sufficient to solve for stationary conditions that occur fairly quickly that is when $\frac{\partial C}{\partial t}=0$.

The solution of equation (7) is performed under the following boundary conditions, namely: $N_{c}$ for $z=0$, and $\frac{\partial C}{\partial z}=0$ for $z=\partial$, which allows us to determine the change in the concentration of oxygen in the thickness of the biofilm $l$ and in subsequent calculations to determine the concentration on the surface of the biofilm $\left.C\right|_{z=0}=C \delta$.

In the general case the reaction rates are described by the following equations:

$$
\begin{aligned}
R_{c} & =\alpha_{1} R_{L}+\alpha_{2} b_{c} \frac{C}{K_{m_{c}}+C} X, \\
R_{L} & =\frac{\mu_{m}}{Y} \frac{L}{K_{m_{L}}+L} \cdot \frac{C}{K_{m_{C}}+C} X, \\
R_{c_{a}} & =\alpha_{1 a} R_{\grave{a}_{L}}+\alpha_{2 a} b_{a_{C}} \frac{C_{a}}{K_{m a_{C}}+C_{a}} X_{a}, \\
R_{a_{L}} & =\frac{\mu_{m a}}{Y} \frac{L_{a}}{K_{m a}+L_{a}} \cdot \frac{C_{a}}{K_{m a_{C}}+C_{a}} X_{a} .
\end{aligned}
$$

In the above equations and dependencies we have $C, \tilde{N}_{\delta}, C_{a}, C_{0}$ - respectively the concentration of oxygen in the biofilm, on the surface of the biofilm, in the aerotank and in the waste waters at the entrance to the aerotank; $C_{p}$ - concentration of saturation (soluble) oxygen in the liquid; $R_{c}, R_{a_{c}}$ - the rate of reactions of using oxygen in a biofilm and aerotanks, taking into account the oxidation velocity of the isolated substances during the death of microorganisms; $W_{a}, W_{p}, W_{\delta}$ - respectively the 
aerotanks working volume, the volume of the liquid in the aerotank, the volume of the elements of the established loading with the fixed biocenosis $F_{\delta l}, F_{\delta}$-respectively the total surface area of the biofilm in the aerotank (reactor), the surface area of the biofilm per unit length of the aerotank (reactor); $K_{C} a, K_{c n}, K_{C}$ - respectively the volumetric mass transfer coefficient, the coefficient between the surface transfer of oxygen in the biofilm, the coefficient of mass transfer of oxygen in the liquid film. The denotation of other variables in the above equations is given in $[1,3]$.

To assess the impact of these mechanisms of supply and consumption of oxygen in the removal of OC it is advisable to consider the limiting cases of the work of the aerotanks in the system of biological waste water treatment.

1. In the absence of fixed biomass (additional loading) the removal of OC occurs only with the suspended active sludge and for the supply and consumption of oxygen the given equations are solved with $N_{c}=0$. In this case the calculation of the parameters of the oxygen regime taking into account the specifics of the oxygen supply systems and the work regime of the aerotank was considered in [4].

2 . In the case when the removal of OC occurs only on the biomass fixed on the load that is without taking into account the action of suspended active sludge the given equations are solved at $R_{a_{c}}=0$.

3. In the case when the removal of OC in aerotanks occurs at the expense of suspended and a fixed biocenosis in determining the optimal parameters of its work the various variants of its location in the volume (in the plan) of the aerotanks and the required area of the surface of the biofilm surface $F_{\delta l}$ (loading elements ) are possible.At this the loading elements (nozzles, grids, etc.) can be located throughout the aerotank volume or more densely and compactly only in its individual sections. Depending on the technological scheme of the location of the elements in the aerotank for length (in volume) and in connection with the received reactions in the biofilm and aerotank the general equations can be greatly simplified. Let's consider further the possible following technological schemes:

a) The load elements are not sufficiently close distributed throughout the length of the aerotank. In this case in the above equations we adopt $\eta=0$ that is the intersurface oxygen transfer may not be taken into account and with sufficient justification the removal of OC in the volume of aerotanks occurs by reaction of zero order and in biofilm by the first order reaction.

Since in equations (9) and (11) $K_{m_{C}} \ll \mathrm{C}$ and $K_{m a_{C}} \ll C_{a}$ then for oxygen in practical calculations the oxidation occurs by the reaction of zero order in a biofilm and in aerotank. So for reactions we have:

$$
\begin{gathered}
R_{c}=\alpha_{1} R_{L}+\alpha_{2} b_{c} X \\
R_{L}=k_{L} L=\frac{\mu_{m} X}{Y K_{m}} L \\
R_{c_{a}}=\alpha_{1 a} R_{a}+\alpha_{2 a} b_{a_{c}} X_{a} ; \\
R_{a}=\frac{\mu_{m a} X_{a}}{Y_{a}}
\end{gathered}
$$


Determination of the concentration of $\mathrm{OC}$ in a biofilm $L(z)$ and in particular on its surface $L_{\delta}$ is given in [5]. Determination of the concentration of oxygen $\mathrm{C}$ in the biofilm and in particular on its surface $C \delta$ occurs as a result of the solution of equations (7), (8) depending on the construction of the loading elements on which the biofilm is formed for example or in the form of flat plates with holes or a net of separate cylindrical rods. At the same time with some approximation we can take for the determination of the reaction $R_{c_{L}}$ the next dependence:

$$
R_{c_{L}}=\alpha_{1} k_{L} L_{\delta p}+\alpha_{2} b_{c} X
$$

where $L_{\delta p}$ is an averaged concentration of OC in a biofilm [5].

b) The loading elements are located at the beginning of the aerotank in its first part - the reactor 1 in which the removal of the OZ occurs due to the fixed biomass and in the second part of it - in the reactor 2 where the removal of OC occurs by a suspended biomass (active sludge) that is a reactor 2 works like a regular aerotank (Fig. 1a).

c) The elements of the load are located at the end of the aerotank in its second part in the reactor 2 in which the removal of the OC occurs due to the fixed biomas and in the first part - the reactor 1 the removal of OC occurs due to the suspended biomass (active sludge) that is the reactor 1 works as a regular aerotank (Fig. 1b).
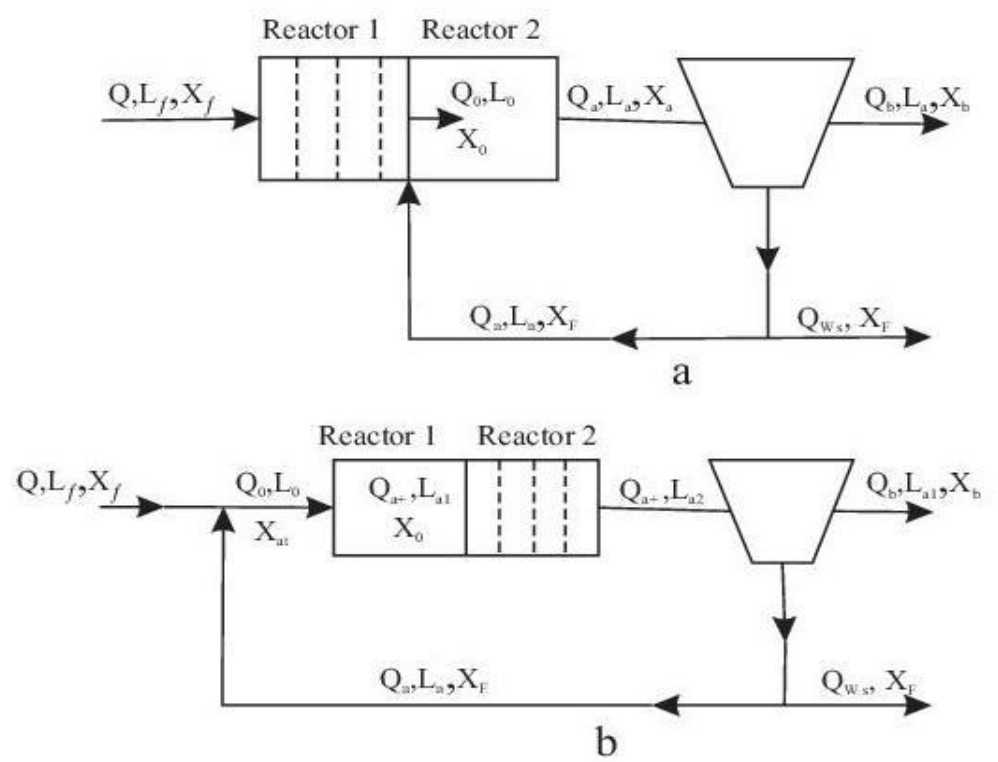

Fig. 1 - Scheme of biological purification in aerotanks: a - fixed biomass in reactor 1; $\mathrm{b}$ - fixed biomass in the reactor 2

Depending on the adopted hydrodynamic regime of the liquid flow the reactors 1 and 2 can work as bioreactors-mixers and bioreactors-displacers. The supply of oxygen for removal of OC in reactors takes place in accordance with the given general mathematical model that takes into account the accepted reactions of OC utilization and oxidation. 
The theoretical substantiation and the methods of calculations of the oxygen regime in aerotanks-mixers and aerotanks-displacers for the above described different technological schemes are considered respectively in [6, 7].

To implement the proposed models and calculations we consider some of the features and prerequisites that have been adopted in the formation of the oxygen regime in aerotanks with an fixed biomasses.

Thus in the above models when we remove OC by the suspended and the fixed biocenosis the linear kinetics of the reactions of the first and the zero orders are accepted and the limits of use of which are limited in particular the values of the concentrations of waste waters which enter to the purification. Therefore in the general case with a sufficient justification in the special literature at the removing of the OC it is proposed to use in the models mainly the kinetics of reactions which is described by the known nonlinear Mono equation [5]. Based on the use of the obtained solutions for the reactions of the first and the zero orders the approximate methods for calculating the required parameters are proposed in accordance with the Mono equation [5]. As a result of the aforementioned in [8] and on the base of the implementation of the above mathematical models a methodic of calculations of the removal of the OC in aerotanks with suspended (active sludge) and with fixed biocenosise (biofilm) in which the kinetics of reactions is described by the nonlinear Mono equation is developed, namely:

$$
\begin{array}{ll}
R_{L}=\frac{\rho_{m} L}{K_{m_{L}}+L}, & \rho_{m}=\frac{\mu_{m} L_{a}}{Y_{a}} \\
R_{a}=\frac{\rho_{m a} L_{a}}{K_{m_{L}}+L_{a}}, & \rho_{m}=\frac{\mu_{m a} L_{a}}{Y_{a}}
\end{array}
$$

At the removal of $\mathrm{OC}$ by fixed biomass in the reaction of an oxygen regime of zero order instead of a variable concentration $\mathrm{L}$ with sufficient justification its average value $L \delta_{p}$ is taken according to the following dependence:

$$
L \delta_{p}=0,5\left(L \delta_{r=0}+L \delta_{z=\delta}\right)
$$

where $L \delta_{r=0}$ is the concentration of OC on the outer surface of the biofilms $(\mathrm{z}=0)$, $L \delta_{r=\delta}$ is the concentration of OC on the inner surface of the biofilm $(\mathrm{z}=0)$.

In order to determine the concentrations $L \delta_{z=0}$ and $L \delta_{r=\delta}$ the solutions of problems for determining the concentration changes in biofilms at different kinetics of reactions are given in the works $[5,6,9]$. Thus the following equation was obtained in [9] which connects the concentrations $L \delta_{z=0}$ and $L \delta_{r=\delta}$ to the conditions of the nonlinear Mono equation:

$$
L \delta_{z=0}=\bar{L} \delta_{z=\delta}-\bar{K} m_{L} \ln \left|\frac{L \delta_{z=0}+\bar{K}_{m_{L}}}{L \delta_{z=\delta}+\overline{K_{m_{L}}}}\right|+\frac{\beta_{L}^{2}}{2 \alpha_{L}}\left(\bar{L} \delta_{z=0}-1\right)
$$




$$
N_{L}=K_{L}\left(L_{a}-L \delta_{z=0}\right)=\lambda_{L} \beta_{L}\left(1-\bar{L} \delta_{z=0}\right)
$$

where $\bar{L}=\frac{L}{L_{a}}, \bar{K}_{m_{L}}=\frac{K_{m_{L}}}{L_{a}}, \alpha_{L}=\frac{\mu_{m} X \delta^{2}}{Y D_{L} L_{a}}, \beta_{L}=\frac{K_{L} \delta}{D_{L}}, \lambda_{L}=\frac{D_{L}}{\delta} L_{a}$

In the case of the necessity of considering the interfacial transfer (IST) according to equation (5) the solution of the problem in particular the determination of oxygen concentration on the surface of the biofilm $C \delta$ was obtained in [9].

In an aerotank (reactor) where the removal is due to an active sludge it is usually necessary to recirculate the discharge $\mathrm{Q}$ which will be determined by the following formula:

$$
Q_{a}=Q(1+r)
$$

where $\mathrm{Q}$ - estimated wastewater discharge, $\mathrm{m}^{3} / \mathrm{h}, \mathrm{r}$ - the degree of recirculation of active sludge which is taken according to the work [10].

An important question when using the proposed models and methods for calculations the oxygen supply of the processes the removal of OC is the definition of unknown mass transfer coefficients $K_{C} a$ and $K_{C_{n}}$ and related to their determination other parameters. If the technological schemes of supplying oxygen and the peculiarities of its use in aerotanks with active sludge were investigated in to a sufficient extent but in the structures in which the removal of OC occurs by fixed on the loading elements biomasses(biofilm) the study of the oxygen regime was provided insufficient. It was assumed at this that the process of removing of $\mathrm{OC}$ is not limited by oxygen that is provided in sufficient quantities of oxygen and is maintained mainly at a concentration close to the concentration of saturation. Among other the processes of oxygen supply of microorganisms in the fixed biofilm and in the form of suspended flakes of active sludge are somewhat different that need to take into account when calculating the consumption of oxygen in the utilization of contaminations by fixed and suspended biomasses.

Taking these features into account when calculating the oxygen regime in reactors with suspended and a fixed biomasses allows more basically to substantiate the determination of the coefficients $K_{C} a$ and $K_{C_{n}}$ as is shown in [1].

In the future on the base of the proposed models and methods of calculations it is necessary to analyze and evaluate their impact in order to ensure the supply of the required amount of oxygen to the place of reactions and the utilization of OC.

As an example of the calculation (simulation) of the oxygen regime consider the aerotank-mixer in which in the reactor 1 the removal of the OC occurs by suspended biocenosis (active sludge) and in the reactor 2 the removal of the OC occurs due to the fixed biomass (biofilm) on the installed load (Fig. 1). This technological scheme of purification from a practical point of view will be more appropriate and more consistent with the current requirements for providing oxygen treatment because in existing traditional aerotanks to provide the proper more higher quality of the waste waters treatment is too difficult and uneconomical. 


\section{Conclusions}

Thus the implementation of the proposed models allows with known geometric and other characteristics to evaluate the influence of oxygen regime on the processes of purification in aerotanks at the different conditions of their operation and to substantiate an economical and efficient technological supply system with oxygen taking into account the features of removing of OC in aerotanks with suspended and a fixed biocenosis. In this case it is possible to substantiate the criteria in which the biochemical oxidation process will be adequately supplied with oxygen that is it will be not limit the kinetics of biooxidation both suspended and fixed biocenosis.

\section{REFERENCES}

1. Oliynik O.J., Airapetian T.S. Reports of National Academy of Sciences. - 2015. - №5. 55-59.

2. Lee K.M., Stensel H.D. Aepation and substrate utilization in a sparged packed - biofilm reactor // WPCF, vol. 58, №11. 1065-1073.

3. Maslun G.S.Problemy vodopostachannya, vodovidvedennya ta gidravliky. - 2013. - 21. 123-142.

4. B.N. Repin, V.I. Bazhenov. Vodni Resursy. - 1991. - №1. 122-130(in Russian).

5. Oliynik O.J., Kolpakova O.A. Ekologichna bezpeka ta pryrodokorystuvannya. - 16. 2014. 68-86.

6. Oliynik O.J, Airapetian T.S. Modeling and calculations of the oxygen regime at the removing of the organic pollutions in aerotanks-mixers with suspended and fixed biomasses. Problemy vodopostachannya, vodovidvedennya ta gidravliky. 2016,-27. 269-279.

7. Oleinik A., Airapetian T. Oxygen regime in research on the work of plug flow aeration tanks with fixed biomasses. // Eastern-Europian Journal of Enterprise Technologies, Kharkiv, 2017, 4/10(88). - P. 4-11.

8. Perez J., Pissioreanu C., Van Loosdrecht M. Modeling biofilm and floc diffusion processes based on analytical solution of reaction-diffusion equations. // Water Research, 2005, vol. 39, issue 7. - P. 1311-1323.

9. Oleynik A., Kalugin Yu., Airapetian T. The use of nonlinear Mono kinetics in modeling a mixing aeration tank with a biofilm on additional loading // Eastern-Europian Journal of Enterprise Technologies, Kharkiv, 2017, 6/10(90). - P. 17-23.

10. SBN V.2.5.-75.2013. Sewerage system. External nets and structures. Main regulations in projecting. K., Ukrainian region ministry, 2013. - 128 p.

Text of the article was accepted by Editorial Team 19.03.2018

\section{Т.С. Айрапетян, С.В. Телима, О.Я. Олійник}

\section{МЕТОДИКА МОДЕЛЮВАННЯ І РОЗРАХУНКІВ КИСНЕВОГО РЕЖИМУ ПРИ ОЧИСТЦІ СТІЧНИХ ВОД В АЕРОТЕНКАХ ЗІ ЗВАЖЕНИМ І ЗАКРІПЛЕНИМ БІОЦЕНОЗОМ}

Анотація. Наводиться методика математичного моделювання i розрахунків кисневого режиму при біологічній очистці стічних вод від органічних забруднень в аеротенках зі зваженим і закріпленим біоценозом. При цьому розглядаються особливості моделювання подачі кисню при очистці в аеротенках-змішувачах і в аеротенках-витискувачах.

Ключові слова: модель; очистка; кисень; органічне забруднення; аеротенкзмішувач; аеротенк-витискувач; біоплівка; активний мул. 
Автори (науковий ступінь, вчене звання, посада):

\section{Айрапетян Тамара Степанівна}

кандидат технічних наук, доцент кафедри водопостачання, водовідведення і очистки стічних вод

Харківський національний університет міського господарства ім. О.М. Бекетова

Адреса робоча: 61002 Україна, м. Харків, вул. Маршала Бажанова, 17

\section{Телима Сергій Васильович}

кандидат технічних наук, старший науковий співробітник Інститут гідромеханіки НАН України

Адреса робоча: 03057 Україна, м. Київ, вул. Желябова 8/4

e-mail: office@hydromech.com.ua

\section{Олійник Олександр Якович}

член-кореспондент НАН України, доктор технічних наук, професор, завідувач відділом

Інститут гідромеханіки НАН України

Адреса робоча: 03057 Україна, м. Київ, вул. Желябова 8/4

e-mail: OliinikOYa@nas.gov.ua 